\title{
MICRONUCLEUS EVALUATION OF EXFOLIATED BUCCAL EPITHELIAL CELLS FROM AUTOMOBILE SPRAY PAINTERS - A PRELIMINARY STUDY
}

Nkiruka Chinonyelum Azubuike ${ }^{1 *}$; Okechukwu Steven Onwukwe ${ }^{1}$; Anulika Obianuju Onyemelukwe ${ }^{1}$; Uzoamaka Charity Maduakor ${ }^{1}$; Iniekong Philip Udoh; Ikenna T. Ikele ${ }^{2}$; Cornelius O. Ogu' ${ }^{1}$; Valentine Chinwendu Okafor ${ }^{1}$

${ }^{1}$ Department of Medical Laboratory Sciences, Faculty of Health Sciences and Technology, College of Medicine, University of Nigeria, Enugu Campus.

${ }^{2}$ Department of Anatomy, Faculty of Basic Medical Sciences, College of Medicine, University of Nigeria, Enugu Campus.

*CORRESPONDENCE TO: Nkiruka C. Azubuike; E-mail: nkiruka.azubike@unn.edu.ng Phone: $+2348036711136$

\begin{abstract}
Automobile spray painters in the Mechanic village at Coal Camp, Enugu State, Nigeria are exposed to genotoxic agents such as the automobile paints and spent engine lubricants which contaminate the soil of their working environment. The present study applied the micronucleus (MN) test on exfoliated oral mucosal cells as a means to assess the genotoxicity risk associated with occupational exposure to genotoxic agents. Two (2) groups of subjects which comprised 30 automobile spray painters and a control group of 30 apparently healthy unexposed volunteers were enrolled in the study. The study participants were all males. Moistened wooden spatulas were used to obtain buccal smears of the participating individuals, and the smears were stained. The presence of MN was assessed under light microscopy and a total of 1000 cells per individual were scored. The results obtained showed that statistically significant increase in $M N$ frequency in buccal epithelial cells of automobile spray painters when compared with the control group $(p<0.05)$. Elevated MN frequency was also observed with increased age, smoking and alcohol consumption habits. MN frequency was significantly affected by the duration of working experience (years) of the spray painters whereas no difference was observed with number of working hours/day. In conclusion, the present study has revealed that automobile spray painters in the Mechanic village of Coal Camp, Enugu State could be under risk of cytogenetic damage from exposure to genotoxic chemicals.

KEY WORDS: Micronuclei frequency; Exfoliated buccal cells; Smoking; Alcohol consumption, Spray Painters; Genotoxicity;
\end{abstract}

The health of humans is influenced either positively or negatively in various ways. Health threats from environmental sources are increasing and have become a growing concern over the years. Many individuals in various settings are occupationally exposed to agents that can cause congenital defects, mutations and even cancer (Hirvonen, 1995). The various routes of exposure to hazardous substances are by inhalation, ingestion and dermal absorption (Benites et al, 2006) which lead to genomic damage. Several types of cancer that affect the skin, pancreas and urinary tract have been attributed to exposure to occupational agents (Santos-Mello and Cavalcante, 1992).
Damage to DNA or chromosomes in humans have been identified by obtaining tissue biopsies or blood samples for lymphocyte and erythrocyte assays (Holland et al, 2008). Micronuclei (MN) assay presented greater advantages over the other techniques, being a minimally invasive method (Stitch and Rosin, 1983). It has continued to gain popularity over the years as a biomarker of genetic damage (Majer et al, 2001) and has served as a tool for the detection and quantification of genotoxic effects of carcinogenic agents. Its information can be used as an early warning of potential risk of developing long-term health problems (Au, 1991).

Submitted $8^{\text {th }}$ February 2019. Published online $14^{\text {th }}$ February 2019. To cite: Azubuike NC Onwukwe OS, Onyemelukwe AO, Maduakor UC, Udoh IP, Ikele IT, Ogu CO, Okafor VC. 2019. Micronucleus evaluation of exfoliated buccal epithelial cells from automobile spray painters - a preliminary study. Anatomy Journal of Africa. 8: 1460 - 1469. 
The MN test involves examination of exfoliated epithelial cells to determine the occurrence of cells containing small extranucleus separated from the main nucleus (Obe and Natarajan, 1990; Ramirez and Saldanha, 2002).

Previous studies have shown increased MN frequency among petrol station workers, mechanics, foundry workers, agricultural workers and hairdressers exposed to chemical substances who are occupationally exposed to hazardous chemicals (Benites et al, 2006; Pastor et al., 2001; Çelik et al., 2003; Rickes et al., 2010; Singaravelu and Sellappa, 2013). Painters are exposed to hazardous compounds in the environment that has drawn major public health concern and these compounds, mostly found in complex mixtures of organic solvents and metals and are known to be potential toxic, mutagenic and carcinogenic agents (IARC, 1989).

Mechanic village at Coal camp (MVCC) is popular area situated in Enugu metropolis, Enugu State, Nigeria. It is occupied by several automobile mechanics, spray-painters, spare-part dealers, autoelectricians, panel beaters and welders. Recently, it has been documented that high levels of polycyclic aromatic hydrocarbons (PAHs) were detected in the water and soil samples within and around MVCC in
Enugu State, Nigeria (Ogbuagu and Ogbonna, 2013). This is due to the wrong disposal of more than $80 \%$ of the used transmission and engine oil on bare grounds around the workshop areas by the workers. These spent engine lubricants are the most commonly generated hazardous wastes in autorepair shops (Iwegbue, 2007; Ipeaiyeda and Dawodu, 2008). Individuals working within MVCC environment are exposed the mixtures of waste chemicals. In addition, automobile spray painters are also exposed to the spray paints upon handling. Since occupational exposure to hazardous chemical agents is of great public health concern (Franco et al., 2008), a provision of further information regarding genetic risks related to exposure to genotoxic agents is pertinent. Therefore, the major objective of the present study was to determine cytogenetic damage in exfoliated epithelial cells of the buccal mucosa of MVCC automobile spray painters by quantitative determination of micronuclei cells (MNC). A relationship between the frequency of micronuclei with other factors such as age, years of working experience, duration of time in working environment/day, alcohol consumption and smoking were also established.

\section{MATERIALS AND METHODS}

The study population comprised 30 automobile spray painters selected randomly in Mechanic Village at Coal Camp, Enugu and a control group of 30 apparently healthy unexposed individuals. The study was conducted in accordance with Helsinki declaration and ethical clearance was obtained from the Health Research and Ethics Committee of the University of Nigeria Teaching Hospital, Ituku-Ozalla [NHREC/05/01/2008B-FWA00002458-

1RB00002323]. Selection of subjects was based on information obtained from questionnaire which included age, smoking habit, alcohol consumption, use of drugs, occupational and non-occupational exposure according to established protocol (Carrano, 1988). Based on occupational exposure, only subjects who have worked for five years and above were recruited. The study participants were all males and written consent from the selected subjects were obtained. The individuals who obliged to participate in the study were apparently healthy and they answered the questionnaire.

Prior to sample collection, the participating individuals thoroughly rinsed their mouths with water to remove unwanted debris. Buccal smears were obtained by scrapping the inside of both right and left cheeks using a pre-moistened sterile wooden spatula. Smearing unto two slides was done and the slides were air-dried, fixed immediately with methanol and stained using May-Grunwald Giemsa staining procedure. Presence of micronuclei cells (MNC) were assessed under light microscopy at x40 magnification and a total of 1000 cells per individual were scored using the criteria described by Tolbert et al., (1992). A single person blindly scored the randomized slides, and cells that were binucleated, dead or in degeneration process, revealing evidence for nuclear fragmentation, karyorrhexis and karyolysis were not included in the assessment. 
Overall effects of age, exposure duration/day, alcohol consumption and smoking were determined using analysis of variance (ANOVA).

\section{RESULTS}

The summary of general characteristics of the participating individuals obtained from the questionnaire is represented in Table 1 . It includes the responses of the subjects on their age, number of working hours/day, number of sticks of cigarette smoked/day, alcohol consumption. Micronuclei (MN) cells were found in the exfoliated buccal epithelial cells of both MVCC automobile spray painters ( $A S P)$ and the unexposed control group (Table 2). However, a statistically significant increase was observed in $A S P$ when compared to the control $(\mathrm{p}<0.05)$. Increase in age and years of working experience were observed to significantly increase $(\mathrm{p}<0.05) \mathrm{MN}$ frequency in $A S P$ (Figures 1 and $2 \mathrm{~b}$ ); however, no difference in $\mathrm{MN}$ was observed

Table 1: Summary of the general characteristics of the participating individuals

\begin{tabular}{|c|c|c|c|}
\hline Characteristics & Control $(n=30)$ & $\begin{array}{c}\text { Spray Painters (n } \\
=30)\end{array}$ & Total \\
\hline $\begin{array}{r}\text { Age Range (years) } \\
18-25 \\
26-35 \\
>35 \\
\end{array}$ & $\begin{array}{l}9(15.0 \%) \\
9(15.0 \%) \\
12(20 \%) \\
\end{array}$ & $\begin{array}{c}13(21.7 \%) \\
13(21.7 \%) \\
4(6.7 \%) \\
\end{array}$ & $\begin{array}{l}22(36.7 \%) \\
22(36.7 \%) \\
16(26.7 \%) \\
\end{array}$ \\
\hline $\begin{array}{r}\text { Smoking Status } \\
\text { Yes } \\
\text { No } \\
\end{array}$ & $\begin{array}{c}26(43.3 \%) \\
4(6.7 \%) \\
\end{array}$ & $\begin{array}{c}22(36.7 \%) \\
8(13.3 \%) \\
\end{array}$ & $\begin{array}{l}48(80 \%) \\
12(20 \%) \\
\end{array}$ \\
\hline $\begin{array}{c}\text { Number of sticks smoked/da } \\
1-5 \\
>5 \\
\mathrm{Nil} \\
\end{array}$ & $\begin{array}{c}12(20 \%) \\
14(23.3 \%) \\
4(6.7 \%) \\
\end{array}$ & $\begin{array}{l}15(25 \%) \\
7(11.7 \%) \\
8(13.3 \%) \\
\end{array}$ & $\begin{array}{l}27(45 \%) \\
21(35) \\
12(20 \%) \\
\end{array}$ \\
\hline $\begin{array}{c}\text { Alcohol Status } \\
\text { Yes } \\
\text { No } \\
\end{array}$ & $\begin{array}{c}29(48.3 \%) \\
1(1.7 \%) \\
\end{array}$ & $\begin{array}{c}25(41.7 \%) \\
5(8.3 \%) \\
\end{array}$ & $\begin{array}{c}54(90 \%) \\
6(10 \%) \\
\end{array}$ \\
\hline $\begin{array}{l}\begin{array}{l}\text { Daily Alcohol Consumption } \\
\text { (bottles) } \\
\qquad \begin{array}{ll}1-3 \\
\\
\end{array} \\
\\
\text { Nil } \\
\end{array} \\
\end{array}$ & $\begin{array}{c}16(26.7 \%) \\
13(21.7 \%) \\
1(1.7 \%) \\
\end{array}$ & $\begin{array}{c}20(33.3 \%) \\
5(8.3 \%) \\
5(8.3 \%) \\
\end{array}$ & $\begin{array}{c}36(60 \%) \\
18(30 \%) \\
6(10 \%) \\
\end{array}$ \\
\hline $\begin{array}{l}\text { Lifestyle } \\
\text { Smokers only } \\
\text { Alcohol drinkers only } \\
\text { Smokers and Alcohol drinkers } \\
\text { Nil } \\
\end{array}$ & $\begin{array}{c}- \\
3(5 \%) \\
26(43.3 \%) \\
1(1.7 \%) \\
\end{array}$ & $\begin{array}{c}- \\
3(5 \%) \\
22(36.7 \%) \\
5(8.3 \%) \\
\end{array}$ & $\begin{array}{c}0(0 \%) \\
6(10 \%) \\
48(80 \%) \\
6(10 \%) \\
\end{array}$ \\
\hline $\begin{array}{c}\text { Working hours/day (hours) } \\
\begin{array}{c}4-6 \\
7-9 \\
\end{array}\end{array}$ & - & $\begin{array}{l}10(33.3 \%) \\
20(66.7 \%) \\
\end{array}$ & $\begin{array}{l}10(33.3 \%) \\
20(66.7 \%) \\
\end{array}$ \\
\hline $\begin{array}{l}\text { Working experience (years) } \\
\begin{array}{l}5-10 \\
11-16 \\
>16\end{array}\end{array}$ & $\begin{array}{l}- \\
- \\
-\end{array}$ & $\begin{array}{c}10(33.3 \%) \\
11(36.7 \%) \\
9(30 \%)\end{array}$ & $\begin{array}{c}10(33.3 \%) \\
11(36.7 \%) \\
9(30 \%)\end{array}$ \\
\hline
\end{tabular}


in $A S P$ who work between $4-6$ hours and those who work above 6 hours daily (Figure 2a).

Increased MN frequency $(p<0.05)$ was observed in control and $A S P$ groups who have a smoking habit compared to individuals who do not smoke in their respective groups (Figure 3a) although markedly increased $M N$ values were obtained in smoking and non-smoking $A S P$. MN frequencies were also observed to increase with increased number of cigarette sticks smoked/day $(p<0.05)$ (Figure 3b). Alcohol consumption was also observed to increase
MN frequency significantly (Figure 4a), and increased number of bottles consumed per day was also observed to increase $M N$ frequency $(p<0.05)$ (Figure 4b). In general, based on lifestyle habits, slightly raised MN frequency was observed among individuals who do not smoke but have alcohol drinking habit. However, significantly increased $M N$ frequency $(p<0.05)$ was observed in individuals who both have alcohol drinking and smoking habits when compared with individuals who neither smoke nor drink alcohol (Table 3).

Table 2: Cytological observations in exfoliated buccal epithelial cells of control and MVCC Automobile Spray painters

\begin{tabular}{lcc}
\hline \multicolumn{1}{c}{ Study Group } & MNC \\
\hline Auto Spray Painters & $17.73 \pm 6.51^{*}$ \\
Control & $6.80 \pm 3.77$ \\
\hline & F-ratio & 62.949 \\
& Sig. & 0.000 \\
\hline MNC: Cells with micronuclei. Data expressed as Mean \pm Standard deviation \\
(SD). ${ }^{*}=$ value is significantly different at $\mathrm{p}<0.05$ when compared with \\
control & \\
\hline
\end{tabular}

Table 3: Effect of lifestyle habits on Micronuclei frequency on exfoliated buccal epithelial of participating individuals.

\begin{tabular}{|c|c|}
\hline Study Groups & MNC \\
\hline Alcohol drinkers only & $8.50 \pm 6.32$ \\
\hline Smokers and Alcohol drinkers & $13.96 \pm 7.17 *$ \\
\hline & $2.67 \pm 2.66$ \\
\hline F-ratio & 8.344 \\
\hline $\begin{array}{cc}\text { Sig. } \\
\end{array}$ & 0.001 \\
\hline \multicolumn{2}{|c|}{$\begin{array}{l}\text { MNC: Cells with micronuclei. Data expressed as Mean } \pm \text { Standard } \\
\text { deviation (SD). } *=\text { value is significantly different at } p<0.05 \text { when } \\
\text { compared with individuals who neither smoke nor drink alcohol [Nil] }\end{array}$} \\
\hline
\end{tabular}




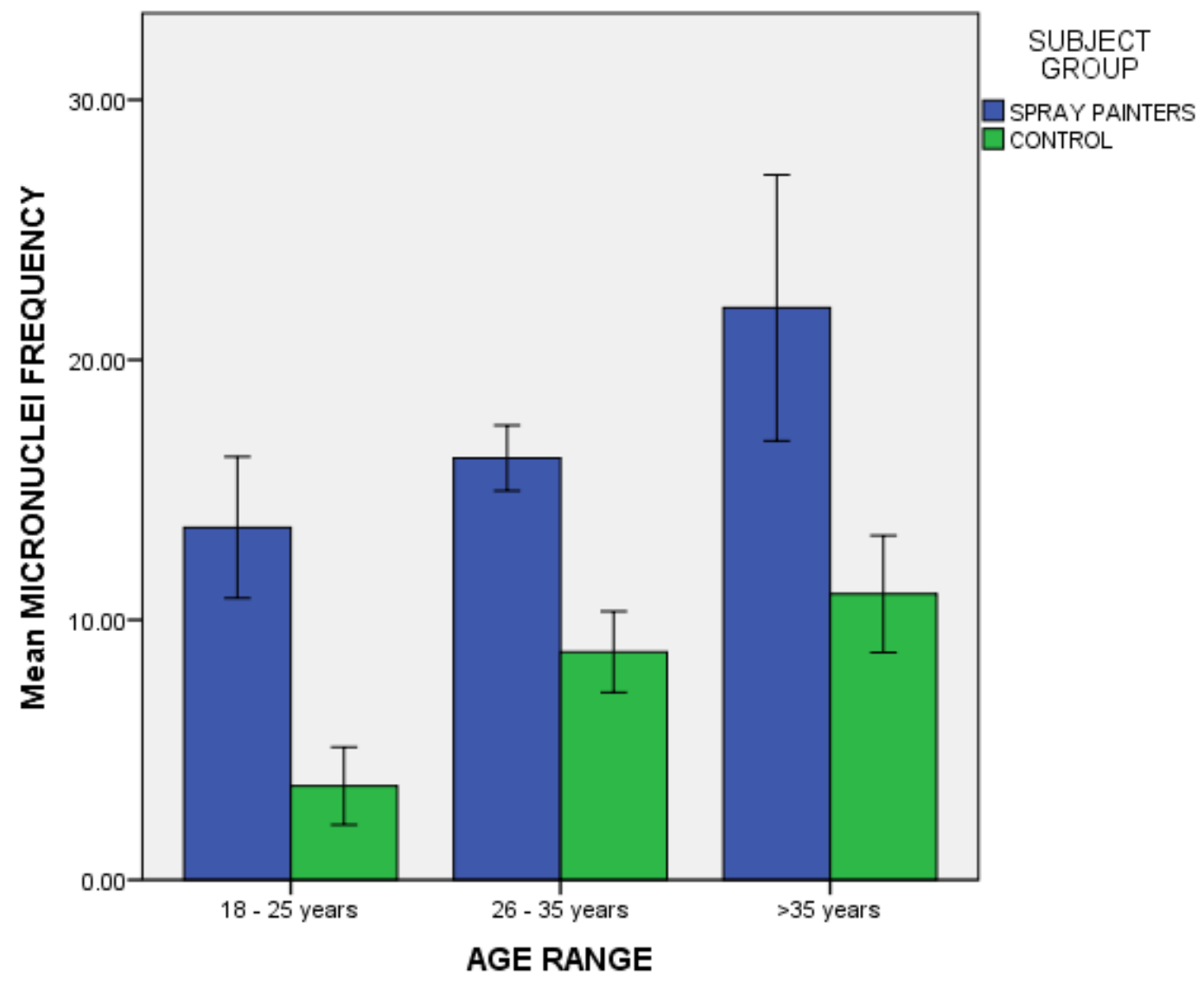

Figure 1: Bar chart showing Micronuclei frequencies of Automobile spray painters and control group in relationship with age.
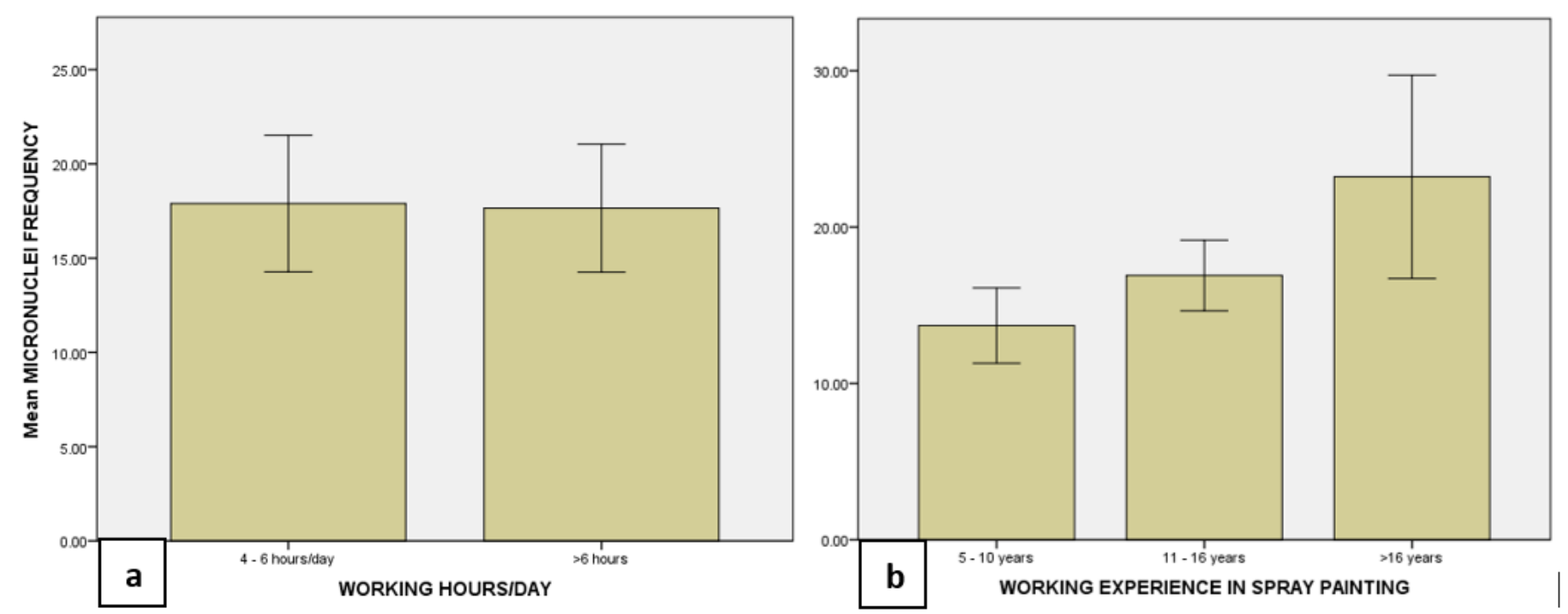

Figure 2: $\quad$ Bar charts showing Micronuclei frequencies of Automobile spray painters in relationship with (a): working hours/day and (b): years of working experience. 

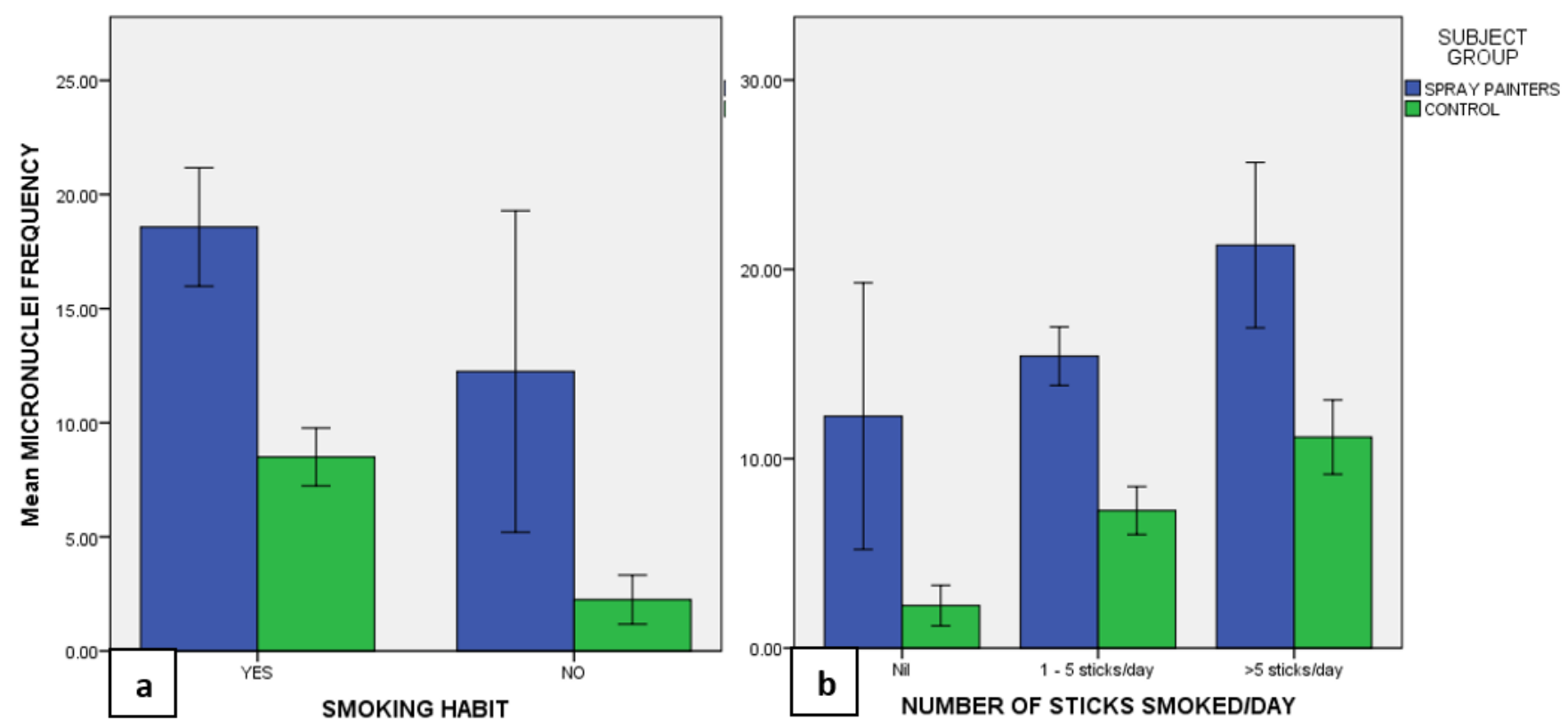

Figure 3: Bar charts showing Micronuclei frequencies of Automobile spray painters and control group in relationship with (a): smoking habit and (b): number of cigarette sticks smoked/day.
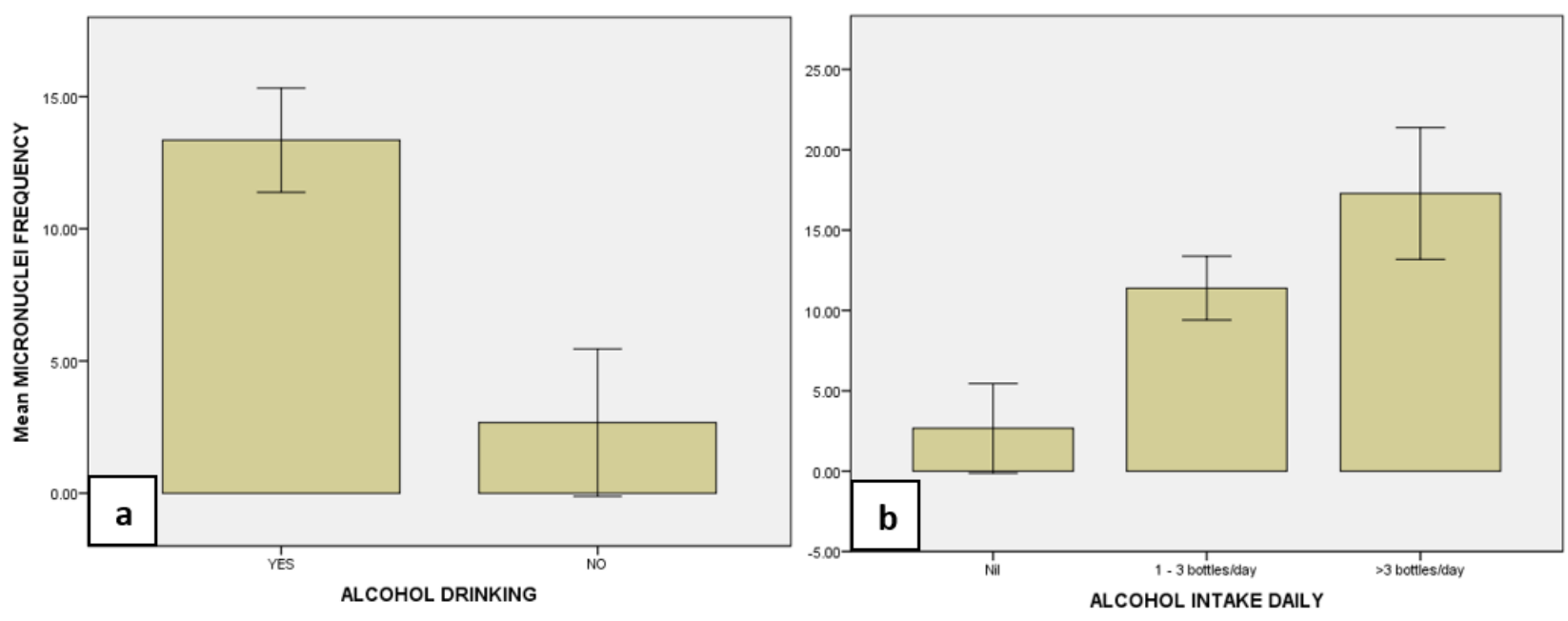

Figure 4: Bar charts showing Micronuclei frequencies of participating individuals in relationship with (a): alcohol drinking habit and (b): number of bottles consumed/day 
Anatomy Journal of Africa. 2019. Vol 8 (1):1460 - 1469

\section{DISCUSSION}

Genotoxin exposure may result from occupational environment, natural and environmental factors, non-specific contamination or industrial accidents (Anderson, 1999). Micronucleus (MN) arise in mitotic cells due to the dysfunction of the mitotic process and breakages of chromosome (Jadhav et al., 2011) and its detection serves as a biomarker to predict cancer risk (Blotching et al., 2000). In the present study, increased frequency of micronuclei (MN) was observed in exfoliated buccal epithelial cells of autospray painters in the Mechanic village at Coal Camp (MVCC) when compared to the unexposed control group. The findings of our study are similar to previous works which documented elevated levels of $\mathrm{MN}$ and other nuclear abnormalities in buccal epithelial cells of spray painters in South India (Khan and Sellapa, 2003). Increased MN frequencies have also been detected in foundry workers, building construction workers, tannery workers and petrol station attendants (Çelik et al., 2003; Singaravelu and Sellappa, 2013Liu et al., 2010; Sellappa et al., 2011).

The epithelium of the oral mucosa maintains itself by continuous renewal of cells. The new cells which are produced by mitosis migrate from the basal layer to replace shed cells in the surface epithelium (Holland et al., 2008). Buccal cell changes such as micronuclei are practical biomarkers of cancer risk in humans. Upon exposure to genotoxins, the basal layer of the mucosa which contains stem cells that may express genetic damage are affected (Reali et al., 1987; Livingston et al., 1990) resulting to chromosome breakage/loss and $\mathrm{MN}$ formation (Holland et al., 2008). There is a correlation between buccal cell changes and the development of malignant tumours (Proia et al., 2006).

Our study also showed that alcohol consumption increased $M N$ frequency both in exposed and unexposed groups. However, we observed that smoking only cigarettes is rare in the participating individuals as most of the smokers are also alcohol drinkers. The significant increase in $\mathrm{MN}$ frequency in participants with both smoking and alcohol drinking habits could have been potentiated by the cigarette smoking since alcohol consumption only did not cause increased $M N$ induction. However, the effect of smoking on MN induction still seems controversial
(Singaravelu and Sellappa, 2013; Tomanin et al., 1991; Azubike et al., 2012). Previous authors have reported that lifestyle factors such as smoking habit and alcoholism are considered as implicative parameters for high degree of nuclear anomalies in people who are exposed to other environmental genotoxins (Holland et al., 2008; Dittberner et al., 1997; Rajkokila et al., 2010; Diler and Ergene, 2010). This is similar to the findings from the present study as these lifestyle habits increased the MN frequencies of the automobile spray painters.

Among the older exposed workers, increased $\mathrm{MN}$ frequency was found connoting an association between aging and the formation of MN. This finding may be attributed to the longer duration of exposure (in years) for most of the older workers than the younger participants. Conversely, Benites et al., (2006) documented no significant change in MN frequency due to age in a study involving gas station attendants. However, other previous studies have also shown association between increased chromosomal instability and aging in correlation with micronucleus formation (Zijno et al., 1996; Bolognesi et al., 1999). A biphasic character in MN frequencies change with regards to age have been documented (Orta and Günebakan, 2012), where a positive correlation exists with ages up to 50 years and a negative correlation with ages beyond 50 years. In this study we report the highest increase in $\mathrm{MN}$ frequency of exposed subjects of $>35$ years (i.e. 35 and above), and the lowest value in ages below 25 years.

In conclusion, our results indicate clearly that automobile spray painters in Mechanic Village of Coal Camp, Enugu State who are occupationally exposed to genotoxins have an increased frequency of cells with $\mathrm{MN}$ connoting potential health risks. It is thus necessary to educate the automobile spray painters and all other workers in the Mechanic village about the genotoxic effects of substances they are exposed to, the need to wear protective automotive clothing, proper handling and disposal of chemicals and engine lubricants used in the workshops so as to alleviate the health hazards they may encounter. 
ACKNOWLEDGEMENT: The authors wish to express their profound gratitude to the volunteers of this study for their candid cooperation.

CONFLICT OF INTEREST: There is no conflict of interest for this study.

\section{REFERENCES}

1. Anderson D, 1999. Factors contributing to biomarker responses in exposed workers. Mutat. Res., 428: 197-202.

2. Au WW, 1991. Cytogenetic assays in monitoring human exposure and prediction of risk. Environ. Mutagen. Carcinog. Teratogen, 23: 236-245.

3. Azubike NC, Achukwu PUO, Okwuosa CN, 2012. Exfoliated Buccal Cell Micronuclei Frequency in Smokers and Non-Smokers. Journal of Applied Sciences, 15(1):10298-10309

4. Benites CI, Amado LL, Vianna RAP and Martino-Roth MG, 2006. Micronucleus test on gas station attendants. Genet Mol Res., 5:45-54.

5. Blotching M, Hofmann A, Lautenschalager C, Berghaus A, Graummnt T, 2000. Exfoliative cytology of normal buccal mucosa to predict the relative risk of cancer in the upper aerodigestive tract using MN assay. Oral Oncol., 36:550-555

6. Bolognesi CL, Lando CE, Forni AL, Landini EL, Scarpato RO, Migliore LU, Bonassi ST, 1999. Chromosomal damage and ageing: effect on micronuclei frequency in peripheral blood lymphocytes. Age and ageing, 28(4): 393-397.

7. Carrano, A.V., 1988. International Commission for Protection Against Environmental Mutagens and Carcinogens. Considerations for population monitoring using cytogenetic techniques. ICPEMC Publication no. 14. Mut. Res., 204(3): 379-406

8. Çelik A, Çava T and Ergene-Gözükara S., 2003. Cytogenetic biomonitoring in petrol station attendants: Micronucleus test in exfoliated buccal cells. Mutagenesis, 18: 417-421.

9. Diler SB, Ergene S, 2010. Nuclear anomalies in the buccal cells of calcite factory workers. Genetics and molecular biology, 33(2): 374-378.

10. Dittberner U, Schmetzer B, Gölzer P, Eisenbrand G, Zankl H, 1997. Genotoxic effects of 2-transhexenal in human buccal mucosa cells in vivo. Mutation Research/Genetic Toxicology and Environmental Mutagenesis, 390(1): 161-165.

11. Franco S.S., Nardocci A.C. and Gunther W.M., 2008. PAH biomarkers for human health risk assessment: A review of the state-of-the-art. Cad Saude Publica., 24: 569-580.

12. Hirvonen A. 1995. Genetic factors in individual responses to environmental exposures. J Occupat Environ Med., 1: 37-43.

13. Holland N, Bolognesi C, Kirsch-Volders M, Bonassi S, Zeiger E, Knasmueller S, Fenech M, 2008. The micronucleus assay in human buccal cells as a tool for biomonitoring DNA damage: the HUMN project perspective on current status and knowledge gaps. Mutation Research/Reviews in Mutation Research, 659(1): 93-108.

14. IARC, 1989. Some organic solvents, resin monomers and related compounds, pigments and occupational exposures in paint manufacture and painting. IARC Monogr Eval Carcinog Risks Hum., 47: $1-442$.

15. Ipeaiyeda AR and Dawodu M, 2008. Heavy metal contamination of topsoil and dispersion in the vicinities of reclaimed auto-repair workshops in Iwo, Nigeria. Bull. Chem. Soc. Ethiopia. 22(3): 339 $-348$.

16. Iwegbue CM, 2007. Metal fractionation in soil profiles at automobile Mechanic Waste Dumps around Port Harcourt. Waste Management Research, 25(6): 585 - 593. 
17. Jadhav K, Gupta N, Mujib BA, 2011. Micronuclei: An essential biomarker in oral exfoliated cells for grading of oral squamous cell carcinoma. Journal of Cytology, 28(1): 7.

18. Khan MR, Sellappa S, 2003. Elevated frequencies of micronuclei and other nuclear abnormalities in buccal epithelial cells of spray painters in South India. International Journal of Pharmacy \& Life Sciences, 4(5): $2680-2684$.

19. Liu HH, Lin MH, Chan CI, Chen HL, 2010. Oxidative damage in foundry workers occupationally coexposed to PAHs and metals. International journal of hygiene and environmental health, 213(2): 9398.

20. Livingston GK, Reed RN, Olson BL, Lockey JE, 1990. Induction of nuclear aberrations by smokeless tobacco in epithelial cells of human oral mucosa. Environmental and molecular mutagenesis, 15(3): 136-144.

21. Majer BJ, Laky B, Knasmüller S, Kassie F, 2001. Use of the Micronucleus assay with exfoliated epithelial cells as a biomarker for monitoring individuals at elevated risk of genetic damage and chemoprevention trials. Mutation Research/Reviews in Mutation Research, 489(2): 147 - 172.

22. Obe G. and Natarajan AT., 1990. Chromosomal Aberrations. Springer-Verlag, Berlin, Germany.

23. Ogbuagu $\mathrm{DH}$ and Ogbonna KN, 2013. Contributions to the environment of priority Polycyclic Aromatic Hydrocarbons from Coal Camp Mechanic Village [CCMV] in Enugu, Nigeria. Research Journal of Pharmaceutical, Biological and Chemical Sciences, 4(4): $1306-1319$.

24. Orta T, Günebakan S, 2012. The effect of aging on micronuclei frequency and proliferation in human peripheral blood lymphocytes. Ind. J. Hum. Genet. 18(1): 95.

25. Pastor S, Gutiérrez S, Creus A, Xamena N, Piperakis S and Marcos R., 2001. Cytogenetic analysis of Greek farmers using the micronucleus assay in peripheral lymphocytes and buccal cells. Mutagenesis, $16: 539-545$.

26. Proia NK, Paszkiewicz GM, Nasca MA, Franke GE, Pauly JL, 2006. Smoking and smokeless tobaccoassociated human buccal cell mutations and their association with oral cancer-a review. Cancer Epidemiology Biomarkers \& Prevention, 15(6): 1061-1077.

27. Rajkokila K, Shajithanoop S, Usharani MV, 2010. Nuclear anomalies in exfoliated buccal epithelial cells of petrol station attendants in Tamilnadu, South India. Journal of Medical Genetics and Genomics, 2(2): 24-28.

28. Ramirez A, Saldanha $\mathrm{PH}, 2002$. Micronucleus investigation of alcoholic patients with oral carcinomas. Genet Mol Res., 1(3): 246-260.

29. Reali D, Di Marino F, Bahramandpour S, Carducci A, Barale R, Loprieno N, 1987. Micronuclei in exfoliated urothelial cells and urine mutagenicity in smokers. Mutation Research Letters, 192(2): 145-149.

30. Rickes LN, Alvarengo MC, Souza TM, Garcias GL and Martino-Roth MG, 2010. Increased micronucleus frequency in exfoliated cells of the buccal mucosa in hairdressers. Genet. Mol. Res., 9 (3): 19211928.

31. Santos-Mello R, Cavalcante B, 1992. Cytogenetic studies on gas station attendants. Mutation Research/Genetic Toxicology, 280(4): 285-290.

32. Sellappa S, Prathyumnan S, Joseph S, Keyan KS, 2011. Micronucleus test in exfoliated buccal cells from chromium exposed tannery workers. International Journal of Bioscience, Biochemistry and Bioinformatics, 1(1): 58.

33. Singaravelu SR, Sellappa SU, 2013. Assessment of genotoxicity in exfoliated buccal epithelial cells of foundry workers occupationally exposed to polycyclic aromatic hydrocarbons. Asian J Pharm Clin Res., 6: 339-342.

34. Stich HF, Rosin MP, 1983. Micronuclei in exfoliated human cells as an internal dosimeter for exposures to carcinogens. Carcinogens and Mutagens in the Environment, 2: 17-25 
35. Tolbert, P.E., Shy, C.M. and Allen, J.W., 1992. Micronuclei and other nuclear anomalies in buccal smears: methods development. Mut. Res., 271: 69-77.

36. Tomanin R, Ballarin C, Nardini B, Mastrangelo G, Sarto F, 1991. Influence of smoking habit on the frequency of micronuclei in human lymphocytes by the cytokinesis block method. Mutagenesis, $6(2)$ : 123-126.

37. Zijno A, Leopardi P, Marcon F, Crebelli R, 1996. Analysis of chromosome segregation by means of fluorescence in situ hybridization: application to cytokinesis-blocked human lymphocytes. Mutation Research/Fundamental and Molecular Mechanisms of Mutagenesis, 372(2): 211-219. 